\title{
CORPORATE SOCIAL RESPONSIBILITY IN THE TOURISM INDUSTRY. SOME LESSONS FROM THE SPANISH EXPERIENCE
}

\author{
Antonio Argandoña
}




\title{
CORPORATE SOCIAL RESPONSIBILITY IN THE TOURISM INDUSTRY. SOME LESSONS FROM THE SPANISH EXPERIENCE
}

\author{
Antonio Argandoña ${ }^{1}$
}

"Tourism poisons itself in small doses." (Said of the industry) (Robledo and Batle, 2002, p. 86)

\begin{abstract}
Tourism has been, and still is, a very profitable industry in Spain. But the Spanish model of tourism development, following a pattern set in the 1950s, is now in crisis. The crisis is apparent in the widespread overdevelopment of tourist resorts and residential facilities in coastal areas, generating high environmental, social and economic costs. In this paper, we describe the Spanish model of tourism, the results it has achieved, the reasons for its longevity and the obstacles facing any attempt to change it. Given the failure of individual, collective and political action to solve the problems of overdevelopment, we ask whether corporate social responsibility and its theoretical foundations and instruments offer a solution.
\end{abstract}

Keywords: Spain, Spanish model of tourism, Corporate social responsibility, Overdevelopment, Tourism, Residential tourism.

Prepared for the project "Corporate Social Responsibility in the Tourism Industry in Bulgaria - the Facts and the Future”, Draft, January 2010.

\footnotetext{
${ }^{1}$ Professor of Economics, "la Caixa" Chair of Corporate Social Responsibility and Corporate Governance
} 


\section{CORPORATE SOCIAL RESPONSIBILITY IN THE TOURISM INDUSTRY. SOME LESSONS FROM THE SPANISH EXPERIENCE}

\section{Introduction ${ }^{1}$}

Tourism - a set of activities aimed at attracting visitors to a geographical area, receiving these visitors and satisfying their demands - is a particularly complex industry. It comprises residential activities (hotels, apartments, camp sites, second homes); transportation (by air, sea and overland); services in the place of origin (tour operators, travel agencies, information services); and services at the place of destination (accommodation, foodservice, sports, leisure, culture, banking, insurance, health care, security). All these activities overlap with and influence one another, as well as residents' other activities. Furthermore, tourism branches into numerous specialties, including sun and beach tourism, ecotourism, rural tourism, ethnic tourism, city tourism, cultural tourism, adventure tourism, esoteric tourism, revolutionary tourism, conflict tourism, religious tourism, movie tourism, business and conference tourism, sexual tourism, medical tourism, volunteer tourism, space tourism... and combinations thereof (Singh, 2005).

As an economic phenomenon, it encompasses all the investment, production, distribution and consumption activities undertaken in the process of attracting, receiving and satisfying visitor demand. Its economic impact is undeniable in terms of the volume of revenues it generates and the pull effect it exerts on other industries. Above all, it is a human and social activity, an activity full of meanings. The complexity we find in tourism is a reflection of the complexity and contradictions of today's society, on the one hand, with its tensions between global and local, sameness and difference; and of tourism's dual nature, on the other hand, as a consumer good and as spectacle or culture. That importance should be given to the economic dimension of tourism is therefore entirely justified; but the other dimensions must also be borne in mind because without them it is impossible to gain a sufficiently objective view of the problems that tourism can cause.

\footnotetext{
1 This paper is part of the activities of the "la Caixa" Chair of Corporate Social Responsibility and Corporate Governance, IESE Business School, University of Navarra. Lena Strandberg is the author of Exhibit 2.
} 
In many countries, tourism has become a mass phenomenon that moves and assembles large numbers of people in limited spaces, resulting in concentrations of tourist facilities, accommodation, second homes and services. This, in turn, has given rise to overdevelopment, which has significant economic, social, cultural, environmental and human costs.

Spain is a world power in tourism. For several decades, Spanish tourism has grown at a spectacular rate, turning Spain into an experimental laboratory for many of the tourism industry's most pressing problems, especially those arising in association with sun and beach tourism. Exhibit 1 gives a statistical overview of tourism in Spain in 2008.

In this paper, we aim to explain how mass tourism in Spain has led to overdevelopment, the causes of overdevelopment, and the possible remedies, seen from the point of view of the social responsibility of tourism companies. First, we describe the Spanish model of tourism, its results and the reasons why it has persisted to the present day. We then discuss the attitudes of the actors involved and the complicities between them. After that, we elucidate the role of corporate social responsibility in tourism companies and in the tourism industry as a whole, ending with the conclusions.

\section{The Spanish Model of Tourism}

The so-called "Spanish model of tourism" is in part the intended result of government policy, largely endorsed and applauded by the private sector; and in part the unintended but foreseeable and foreseen result of that policy and private agents' response to it.

It is not an exclusively Spanish phenomenon, of course, but part of a global model which, with variants, has flourished on all continents. This is an important point, as it influences whether and to what extent the model can be changed, insofar as international players try to ensure that the rules of the game stay the same around the world.

Nor is it a static model. There have been major changes in demand, in public policy, in the attitudes of society and in the response of tourism industry players. Even so, it is still appropriate, in our view, to speak of a Spanish model of tourism, one that retains many of the features of the original and that has given rise to the tourism and real estate overdevelopment that concerns us here.

That model is founded on certain premises and policies, which in turn have created certain incentives. The premises were established in the 1950s and '60s and can be summed up as follows: 1) Europe offers a large potential market for Spanish tourism; 2) Spain has high potential to attract international tourism, given its natural attractions (the three Ss: sun, sand and sea), and 3) to attract tourism, Spain needs an abundant supply of low-cost accommodation and the necessary transportation infrastructure and other services. These premises influenced the approach to tourism in terms of supply (volume and quality of accommodation and services) and demand (visitor characteristics and expectations).

This model embodied the tourism policy that was implemented from the 1950s onward, when tourism experts, entrepreneurs and policymakers "discovered" what tourism could do for Spain's economic and social development. As we said earlier, it was not an original invention. 
It had already been discovered and implemented in other countries and was even explicitly advocated by international bodies. ${ }^{2}$

The initial model was built on three pillars, which have remained unchanged over the years:

1) The country's attractions: good climate, pleasant environment, a touch of cultural, artistic and culinary exoticism, and security - all at low prices. Tourism policy was aimed at showcasing these attractions, publicizing them and making them accessible to foreign visitors.

2) Government involvement, through subsidies for foreign promotion (country image), stimuli to the private sector (mainly tax benefits and cheap loans for the construction of accommodation and homes) and investment in accessibility (roads, railroads, ports, etc.). ${ }^{3}$

3) The private sector, which provided hospitality (hotels, camp sites, restaurants) ${ }^{4}$ and other services, initially at a fairly basic level (foreign exchange, shops, leisure facilities, etc.).

\section{What the Model Achieved}

Throughout the second half of the twentieth century, the economic results of the model were very positive. Tourism experienced strong growth and became a major source of foreign exchange, helping to finance the current account deficit. Large numbers of jobs (many of them seasonal) were created in areas that had no viable economic alternative. Town councils in tourist areas saw a sharp increase in tax revenues, allowing them to modernize infrastructure and finance public services. Construction expanded, both in hotel facilities and homes and in infrastructure. And other industrial and service sectors (food, distribution, retail, financial services) benefited, while the standard of living in tourist areas rose quickly, creating further opportunities for income generation, job creation and entrepreneurship, and enhancing residents' wealth.

Tourism brought benefits in other areas, too, through the opening of Spanish society, exposure to other cultures, language learning and foreign travel. It even earned the government extra support through the good will of citizens who had benefited from the rise of tourism and the improvement of Spain's image abroad.

Inevitably, there was a downside. The main limitations of the model soon manifested themselves (Rivas, 2009, p. 88): excessive geographical concentration (Mediterranean coast and Balearic and Canary Islands); seasonality (summer tourism, which meant that facilities were

\footnotetext{
${ }^{2}$ See, for example, the report by the International Bank for Reconstruction and Development (1962), now the World Bank; cfr. Rivas (2009), p. 85.

3 According to Rivas (2009), p. 83, the tasks of government also include building awareness of the importance of tourism as a driver of economic and social development, in order to overcome the resistance of certain social and political groups to what they see as the abandonment of industrialization as a key aspect of development policy or the surrender of the country's cultural distinctiveness.

${ }^{4}$ The public sector also promoted state-owned tourist accommodation, especially in the early years (the Paradores group).
} 
underused throughout the rest of the year); visitor origin (European visitors, giving rise to demand risk); and motivation (overspecialized in sun, sea and sand).

Also, sun and beach tourism has environmental, esthetic, social and human costs. When this type of tourism was first introduced to Spain, more than half a century ago, concern for these issues was generally very limited. The governments of the time were more interested in achieving sustained (not necessarily sustainable) high growth and the tourism industry itself was only just starting to realize its potential and had neither the patience nor the incentives to adopt policies that would be sustainable in the long run. The same applies to the impact of tourism on the quality of life of local communities, their characteristics and culture, the services available to their inhabitants, etc.

The point here is that, in tourism, there are significant external effects, or externalities. An externality is the effect one person's action has on other people who have no share in the transaction, so that the effect is not reflected in the cost of the good or service produced. Where there is a negative externality, the person who performs the action obtains an extraordinary profit (because part of the cost is borne by someone else) and so has an incentive to repeat the action, thus generating further externalities and increasing the negative impact on the other parties involved.

Externalities are crucial to understanding how the Spanish model of tourism became established. The developers of a large beachfront hotel probably know that the hotel will spoil the landscape, make the area less attractive and impose a burden on the local community. But they have no incentive to take these adverse effects into account in their decision. They are more likely to confine themselves to a simple cost-benefit analysis, arguing that the influx of tourists will raise the standard of living in the local area, create employment opportunities, push up land values and attract new businesses, so that, in the end, everyone wins. And very often they do: local people as a whole, or a large proportion of them, benefit from the growth of tourism. To some extent this makes them hostages to the established model of tourism. They all lose in some ways (quality of life, traditional culture, pleasanter environment), but gain in others (employment, income, wealth) and so oppose any attempt to change the model. ${ }^{5}$

Moreover, the benefits are mainly short-term and are concentrated in a small number of agents, whereas the generally longer-term costs affect more people less severely and possibly over a greater distance and time. The gain in wealth from building a hotel on a piece of waste land is immediate and concentrated, whereas the negative externalities (pollution, water consumption, overcrowding of beaches and roads, etc.) persist over time, affect future generations and extend beyond the immediate vicinity (marine pollution affects other areas, congestion spills over into neighboring counties, the additional water consumption burdens remote infrastructures, waste accumulates elsewhere, and so on).

\section{Changes in the model}

After a while, there was talk of the Spanish model of tourism having "exhausted" its potential. Exhaustion, in this context, is primarily an economic concept, manifested in stagnant visitor numbers and average spending, and thus excess supply. It has to be admitted that the figures

\footnotetext{
${ }^{5}$ Whether future generations of residents, who did not experience the benefits that tourism brought when it was first introduced, will still be willing to pay the costs is a different matter.
} 
for the 1990s show no sign of exhaustion, with strong income growth in Europe, low interest rates, macroeconomic stability under the single currency and abundant credit (Oliver, 2005). Since the 1980s, however, the suspicion (or fear) that the model has outlived its usefulness has been unrelenting. In any case, the doubts about the model reflect deeper problems: overcrowding, congestion, destruction of the country's natural attractions, real estate speculation, environmental degradation, deterioration of supply (low-cost, low-spending tourism), corruption, and so on (Vera, 1994).

The pattern of tourism is not static, but changes over time. In Spain, over the period we are considering, certain market segments responded to the changes. Demand continued to grow, but the structure of demand changed, forcing participants to adapt. Spain remained a favorite sun and beach destination, now affordable to many more visitors, but visitors' expectations regarding service and quality, including environmental quality, were different. This led to the development of new offerings, including cultural tourism, city tourism, sport tourism, rural tourism and ecotourism. The seasonality of the tourism industry changed, too. With low-cost air travel, many more people could afford to take holidays in Spain, as well as frequent short breaks during the year.

Spain also faced stiffer competition. Besides the traditional destinations (France, Italy), new ones emerged, including the Adriatic coast, the Black Sea, North Africa, Greece, Turkey and the Middle East, offering much the same attractions as Spain at lower prices, though usually with lower quality. For many years, the competition was handicapped by political insecurity and conflict and lack of tourism infrastructure, while Spain enjoyed certain advantages of location and country image in important market segments. All this has been rapidly changing, however.

Naturally enough, the tourism supply in Spain has adapted to these and other changes, including the growth of domestic tourism. Other parts of Spain, including inland regions, have entered the market with new attractions as a complement to, or substitute for, traditional sun and beach destinations. These other attractions include city tourism, cultural tourism, rural tourism, adventure tourism, sport tourism (skiing, golf, water sports) and cruise tourism (Barcelona is Europe's leading cruise port). In many ways, Spain now offers much more than sun, sea and sand.

\section{Persistence of the Spanish Model}

In spite of the changes, the traditional model of tourism still plays a large (probably too large) role in the industry. It still dominates in many coastal areas and is the core around which other models have evolved (golf tourism, sailing tourism, sport tourism, etc.). ${ }^{6}$ The traditional model has survived basically for four reasons: 1) the industry's physical capital, which is still there, dominating much of the coastline, as are its environmental, social and human costs; 2) the incentives, which still apply, especially in relatively undeveloped areas, so that the dynamic continues; 3) the widespread development of residential properties for foreigners and second homes for Spaniards, which remains deeply intertwined with tourism, and 4) the failure of successive governments to provide sufficient incentive to change the model of tourism development. Let's look at each of these factors in turn.

\footnotetext{
${ }^{6}$ Sun and beach tourism absorbs approximately $82 \%$ of hotel beds, while the second largest category, cultural and city tourism, absorbs only 8.2\% (Consejo Español de Turismo, 2006).
} 


\section{1) Physical capital and investments}

Tourism is a service, but requires a substantial amount of physical capital, ranging from airports and highways to hotels, retail premises, leisure facilities and restaurants. Many of these investments have a long useful life, are difficult to adapt to other uses and are mutually complementary. So once tourism has established itself in an area, it can be changed only slowly or (if it has to be done quickly) at great cost. Time is an important factor. Any adjustment will be less traumatic if it takes place over a longer period. On the other hand, problems can become endemic.

The costs of adaptation extend to other industries (if we want more sophisticated, higher-priced hotels, for instance, we will also need to promote higher-quality services) and may require improving the area's image in the eyes of potential visitors. All this suggests that as a particular type of tourism develops, industry players may become locked into a not always virtuous circle from which it is difficult to escape.

\section{2) Incentives}

Negative externalities have been a known fact of economics since ancient times. The solutions are similarly well known; basically, they consist of a combination of taxes and subsidies, or regulation. For example, if a hotel has adverse environmental effects on other agents, nearby or far away, the authorities can levy a tax on the polluting activity in order to reduce it. They can also compensate those affected, or subsidize investments in decontamination equipment. Or they can limit the amount of pollution (e.g., $\mathrm{CO}_{2}$ emissions) that hotels are allowed to generate, or restrict the use of certain polluting agents, etc.

In other words, government (central, regional or local) has an important role to play in managing the problems caused by tourism, just as it contributed (and continues to contribute) to creating those problems through the policies it has adopted. For instance, government may prevent overdevelopment by limiting construction in coastal areas; by regulating the minimum distance between buildings, the maximum height of new developments and the minimum width of roads; by providing for green areas and spaces for services; by establishing rules on water and energy use, etc.

Here too, however, the allocation of responsibilities to the different levels of government raises a problem of incentives. Generally speaking, governments are neither unaware of the need for such measures nor lack the means to implement them. The problem, rather, is one of political will. Governments often are "hostage" to tourism development.

Many countries and regions vigorously promote tourism despite the possible or probable longterm costs because it is the only option for economic development. Their hope is that the region will achieve a higher standard of living and sustained growth before the model becomes unworkable or the costs have to be paid. ${ }^{7}$

Another reason why the model is so enduring is the perverse incentives it entails. Governments (especially regional and local governments) tend to benefit, directly or indirectly, from tourism booms. Tourism brings higher tax revenues and central government subsidies with which to finance new services and so win votes and build a reputation for good government. The costs

\footnotetext{
${ }^{7}$ This would mean too low a discount rate: it underestimates the future costs compared to the immediate benefits.
} 
will have to be paid, but not until sometime in the future and then by someone else. Tourism, real estate development and public works also provide opportunities for corruption in connection with political party funding or the personal enrichment of government representatives and public officials.

The longevity of the model is aided by what might be termed the "demonstration effect," i.e. the incentive to imitate the policies or actions of other players or other regions, whether to secure similar benefits (access to the "virtuous" circle of real estate and hotel development, for instance), or not to lose out (e.g., not to become a green area for neighboring cities or, worse still, the site of a waste dump), or even as a political alibi (to be able to say that the same policies have been implemented in other places).

Industry structure may be another factor making the model less amenable to change, though this argument should not be overstated. For decades Spanish tourism companies complained loudly about large foreign tour operators controlling the market. Foreign firms were blamed for the economic difficulties encountered by Spanish hotel owners. If foreign firms were able to dominate, however, it was precisely because the Spanish model was so weak, over-dependent as it was on demand from a small number of countries and with intense supply-side competition based almost exclusively on price and commoditized products. Given this industry structure, source country tour operators and travel agencies were able to concentrate demand and accumulate market power, appropriating whatever rents might remain in the fragmented supply, with the exception of large hotel groups and players in certain market niches that still retained some market power. ${ }^{8}$ In addition, the tour operators offered Spanish hotel owners and developers cheap credit in return for the right to book large numbers of rooms years in advance at preset low prices, further demonstrating the weakness of the model. ${ }^{9}$

The upshot of all this has been that the same mistakes have been repeated and governments have been reluctant to correct them, despite reiterated statements of intentions (Barke and Towner, 2004). The tourism industry in Spain continues to be oriented toward quantitative growth. Plans to regulate regional development and the quantity and quality of tourism products and services have been largely ineffective because the prevailing incentives work against them. What few corrective measures have been taken (Agarwal, 2002) have been ad hoc (green areas, special environmental protection plans) and often reinforce the established model (e.g., investments in infrastructure to facilitate the arrival of more tourists), without an overall vision, merely shifting costs from one area to another (e.g., from the already congested coast to as yet unspoiled inland areas).

In many cases, they have been contradictory, with governments promising to respect the environment while at the same time giving the green light to aggressive investments in poor quality hotels, developments and shopping centers that encroach on beaches and conservation areas (Vera and Ivars, 2004, p. 177). The image this has created is of a lowest-common-

\footnotetext{
${ }^{8}$ That problem has been considerably reduced, partly because tourists are much more independent now that they can put together their own itineraries and book their holidays online, bypassing the traditional package holidays that gave tour operators their ascendency, and partly because the supply is now more diverse (rural tourism, sport tourism, city tourism, cultural tourism, etc.), so it is not so easy for source country aggregators to capture the rents.

${ }^{9}$ All this was further complicated by heavy dependence on foreign capital. Many large developments were carried out by multinationals, based on models designed for global markets, with strict short-term profitability targets (Shaw and Williams, 2004, p. 223).
} 
denominator type of hotel, pool and beach tourism, ${ }^{10}$ even though the brochures and web sites continue to promise a taste of paradise in traditional villages with a vibrant local culture and an untainted environment (Barke and Towner, 2004, pp. 166-168).

\section{3) Residential developments}

The Spanish model of tourism, as we have described it, is not confined to hotel construction but also includes residential development, especially in the Balearics and Canaries, the Costa Blanca and the Costa del Sol, giving rise to what is known as residential or real estate tourism, or intensive suburban development (Iribas, 2000; Mazón, 2002), i.e. "a model of supply driven by property developers, not tourism developers, and serving mainly speculative interests” (Mazón, 2001, p. 265, quoted by Mantecón, 2008, p. 128). ${ }^{11}$

Intensive suburban development started quite early in the form of second homes for Spaniards or for rent (and later, sale) to foreigners. The boom, however, came in recent decades, driven by increased life expectancy, rising income levels, aggressive mortgage lending and low interest rates, coupled with new trends among high and medium-high income Europeans, who were on the lookout for areas with a pleasant climate, good services, cultural quality, etc., for retirement or long-stay second homes ${ }^{12}$ (Casado, 2004; Huber, 2000; Rodríguez et al., 2000). ${ }^{13}$ In recent years, as a result of this boom, more homes have been built than would normally be required and large stretches of coast and farmland have been built up.

Residential tourism is admittedly something of a misnomer, as it is not strictly tourism but a real estate activity. As a term it "tells us little about the foreigners who buy homes in Spain with no kind of tourist expectation; nor does it help differentiate between this supposed category and second homes in general" (Díaz, 2008, p. 65). Yet residential tourism has unquestionably shaped the landscape of many tourist areas and is part of the overdevelopment we are concerned with here, as the areas that attract short-stay tourists are the same as those that attract long-stay Spanish and foreign residents and second home owners, drawn by the same attractions and services. ${ }^{14}$ This symbiosis of tourism and land use planning has been characteristic of the overdevelopment of many areas of Spain in recent years, especially on the coast but also, to a more limited extent, in mountain areas, around golf courses, etc., and has

\footnotetext{
${ }^{10}$ And also, in some places, bar and night club tourism: cfr. Shaw and Williams (2004), pp. 223-225.

11 Residential tourism can be defined as "the economic activity of developing, building and selling residential tourism properties (the non-hotel sector), outside the owners' usual places of residence, for summer vacation use or as permanent or semi-permanent residences, to meet the demand for new forms of mobility and residential options in advanced societies" (Mazón and Aledo, 2005, pp. 18-19). They are a subset of second homes, which are homes that "are used only part of the year, seasonally, regularly or sporadically - during holidays and at weekends, for example...” (Cortina et al., 2002, p. 95). Cfr. Mantecón (2008), p. 130.

12 The occupants of many of these homes develop complex patterns of mobility, involving shorter or longer stays in their second homes and main homes (which in many cases cease to be their main homes). Cfr. Flognfeldt (2002), Gustafson (2001, 2002), 0’Reilly (2000), Salvà (2005).

${ }^{13}$ Mantecón (2008, p. 129) calculates the number of non-hotel beds as a percentage of the total number of beds available in various towns in the province of Alicante in 2006 as follows: 99\% of the total in Torrevieja; 98\% in Santa Pola; 96\% in Denia, and 93\% in Altea.

${ }^{14}$ Second homes owned by Spaniards have mushroomed along the Mediterranean coast (Alicante, Tarragona, Costa Brava), but also in other coastal areas (Galicia and the Atlantic and Cantabrian coast) and in rural and mountain areas. In coastal areas, they have tended to be located away from the residential areas for foreigners, usually leaving the beachfront to the foreigners. This has not prevented overdevelopment, however.
} 
greatly magnified the social, human, environmental and economic impact. It has changed the demographic and socioeconomic makeup of areas affected by residential tourism, increased the environmental damage, altered Spaniards' perceptions of their standard of living, and driven up house prices, again to the detriment of Spanish residents. Furthermore, as tourism and real estate development have been uncoordinated, the growth in residential tourism has been at the expense of the quantity and quality of services available.

\section{4) Tourism policies}

Lastly, successive governments have been unwilling or unable to draft and implement ambitious tourism policies that would transform the model or at least contain its costs (Moreno, 2007; Pellejero, 2004; Rivas (2009).

In the 1960s, tourism development policy consisted basically of promoting hotel construction. In the 1970s, it was designed to slow the rate of construction, as the oil crisis had curtailed demand. And in subsequent decades it involved modernizing existing hotels to adapt them to changes in demand and meet tourists' new needs and expectations.

At no point was there any attempt to implement a regional development policy departing substantially from the model inherited from the 1950s, initially because the growth of tourism seemed more important than regional development and later because the 1978 Spanish Constitution gave Spain's seventeen Autonomous Communities legislative, executive and administrative powers in the areas of tourism, regional development and environmental planning. The central government was thus deprived of the power to manage these three areas, which are precisely those most directly affected by tourism. In the 1990s, the only role left to central government was that of harmonizing the various public or private sector interests involved, while creating new channels of dialogue, coordination and cooperation, with the growing participation of the private sector but not all the industry's stakeholders, only the dominant ones. Though doubtless an interesting task, this was not the most useful contribution government could have made.

The outcome of half a century of tourism policy, therefore, has been disappointing. The policy was effective at first, when the government concentrated on promoting tourism initiatives, with considerable public sector involvement. When the industry ran into difficulties, however, almost always due to quality and quantity imbalances of supply and demand, the policy was reactive, rather than proactive. Once the Constitution devolved powers to the regional governments, which were too jealous of their rights to allow the central government to take an active role in promoting a change of model, tourism development became highly fragmented. And when conflicts arose (whether due to the political and economic crisis of the seventies or the tensions between central and regional government in the nineties), the policy was effectively to defer decisions. One positive aspect, however, was the growing recognition that the private sector should play a leading role in tourism development. 


\section{Attitudes and Complicities}

The problems we have identified will be easier to appreciate if we briefly outline the attitudes of politicians, members of government, citizens, media, academics and entrepreneurs toward tourism and urban development. To some extent, these attitudes can be characterized in terms of two extremes (García-Canclini, 2005):

1) The "utilitarian" attitude, which emphasizes the (mainly economic) benefits of tourism: wealth and employment creation, economic development, cultural diffusion, social interchange, and so on. From this point of view, tourism's contributions to society and the economy most probably outweigh its disadvantages.

2) The "paranoid" attitude, which stresses the negative aspects of tourism, especially in areas beyond the economic sphere: overcrowding, environmental damage, commercialization, trivialization of culture and society, etc.

These two attitudes can be observed in all societies, along with a broad range of intermediate positions. Both have solid foundations, but both also draw on ideological attitudes that make it very difficult to avoid confrontation. In the case of the Spanish economy, Mantecón (2005, p. 405; 2008, p. 138) has identified five positions that reflect these attitudes very clearly. They are characterized below:

\section{1) Unconditionally supportive}

Unconditional supporters of the established model of tourism include property developers, some hotel owners and some politicians and academics. For them the model simply reflects the law of supply and demand and the market must be allowed to operate freely, virtually without interference (only the minimum regulation necessary to control the environmental impact), while maintaining the incentives that have characterized the model from the outset (public promotion of tourism, investment in infrastructure and services, tax benefits and cheap credit, etc.).

In these observers' assessment, the Spanish model of tourism has been a good thing, contributing positively to wealth, income and employment creation. As they see it, the future lies in tourism. They accept that the model has costs, but believe that the costs are clearly outweighed by the benefits. Accordingly, they see no need to amend the model. In any case, they hope to see continued promotional and advertising efforts and improvements to communication and service infrastructure.

\section{2) Permissive}

Like the unconditional supporters, those with a permissive attitude believe that the model is based on the law of supply and demand. Overall they agree that the positive effects (especially the economic effects) dominate the (mainly environmental) negative ones. Efforts should be aimed at attracting tourists with higher spending power and specific cultural and sporting interests (golf, marinas, skiing, cruises), while curbing certain residential and hotel developments, improving service quality and infrastructure, broadening the range of leisure activities on offer and minimizing environmental impacts. This is a position shared by many citizens and political parties, municipal tourism experts, academics, tourism entrepreneurs, etc. 


\section{3) Critical but legitimizing}

Many other citizens and political parties and some hotel owners' associations and academics consider that the model reflects the law of supply and demand, but that real estate and construction interests are too powerful. Their view is more nuanced: the model has quite a few minus points, although probably outweighed by the plus points. In any case, they consider a change of model unlikely in the short term.

In the search for solutions they are both optimistic and skeptical. They believe tourism has a great future, but only if there are major changes, especially in land use planning. They want to see a reduction in environmental impact and improvements in infrastructure, services and leisure facilities in order to attract higher quality tourism and higher spending tourists.

\section{4) Strongly critical and delegitimizing}

Those who take this view say that the model flouts rationality and is dictated by the interests of real estate developers and construction companies, with the connivance of policymakers (corruption). Thus, the costs are socialized while the benefits are privatized. Their overall assessment of the model is sharply negative, mainly because of its environmental impact.

They are skeptical and pessimistic about solutions and see few alternatives. Tourism, in their opinion, is no longer the future. They therefore want to see urgent measures to curb the growth of tourism and real estate development and diversify economic activity, accompanied by investments in infrastructure and social services. This position is shared by many left-wing and environmental parties and academics and some hotel associations.

\section{5) Radically critical}

According to the more radical critics, what Spain has at present is not a model of tourism, but speculative urban development based on exploitation (real estate swindles, corruption, and mafia). Environmental aggression and latent social conflict make the model unacceptable.

Those who hold this view are highly pessimistic about finding a solution; they see hardly any alternatives and think it is probably too late anyway. They want the government to halt all urban development immediately and reorganize economic activity, which is something that cannot be entrusted to the market. This is the attitude of some environmentalists and academics.

Given this diversity of economic, social, media and political attitudes toward the Spanish model of tourism, the debate clearly cannot be easy, precisely because it tends to be conducted in extreme, ideologically defined terms. For some, tourism is untouchable because it is the livelihood of large parts of the country: the well-being of many families and even the survival of entire populations depend on it. For others, it is the devil's own work and causes irreversible harm to the environment and society, justifying, if not an outright ban, at least a moratorium on further development and a winding down to significantly lower levels, probably within the framework of a "different" organization of society. 


\section{The Attitude of Tourism Entrepreneurs}

What is the position of the entrepreneurs most directly involved in the economic activities linked to tourism (hotels, foodservice, real estate, etc.)? How do they view the existing model? The following are arguments that many of them would probably endorse: $:^{15}$

1) Any discussion of the tourism model must start from an acknowledgment of the significant benefits it has brought (and continues to bring) to the Spanish economy.

2) Any alternative to the traditional model must be capable of delivering comparable results (unless the aim is to establish a different model of society). ${ }^{16}$

3) In areas that have not yet developed their full tourism potential, a commonly used argument is that "you have to scale up first before you can scale back." It is not fair, they say, to curb developments that have not yet caused any problems (pollution or congestion) merely because mistakes were made elsewhere. For obvious reasons, this argument is not accepted by entrepreneurs in other areas.

4) For many, then as now, the benefits outweigh the costs, so no radical overhaul of the model is needed. (This argument naturally depends on how one measures the costs and benefits. $)^{17}$

5) Others contend that we have insufficient evidence to know whether the model needs changing or not, especially as it is so difficult to assess the long-term consequences of environmental degradation (which has many causes, of which tourism is only one). ${ }^{18}$ To some extent, this would justify allowing the current model to continue, with certain adjustments.

6) Many players in the tourism industry believe that traditional sun and beach tourism has reached saturation point and that the adverse economic and environmental consequences are already apparent.

7) The model is easy to imitate and is the easiest way to access the mass tourism market. ${ }^{19}$ Spain will only be able to hold onto its advantage if its coasts are genuinely more attractive than those of other countries, which is moot.

\footnotetext{
${ }^{15}$ These arguments are not based on surveys of tourism entrepreneurs.

${ }^{16}$ Or unless a compensation system is instituted for the losers, which is likely to be too expensive and to generate perverse incentives.

${ }^{17}$ Economics may help make the analysis, but its contribution will never be decisive because it always starts from (often implicit) assumptions that are arguable (regarding the importance of species diversity in a natural space, for example).

${ }^{18}$ Those involved in this kind of debate do not usually form their opinion based on a detailed analysis of costs and benefits, but more usually based on their perception of political, social, media and academic discourse, starting from a (subjective) assessment of any improvements in their personal circumstances or immediate environment, plus a few personal experiences.

${ }^{19}$ Just as labor-intensive industries (textiles, apparel, footwear) are the first to prosper in a country that is starting to develop economically.
} 
8) A radical change of model would entail significant costs, so any adaptation would best be undertaken over a period of many years. ${ }^{20}$

9) Many tourism entrepreneurs think that the best policy is the one already in place, which should simply be implemented more thoroughly (i.e. improve infrastructure and services, change country image, diversify, invest in leisure services and, above all, act more decisively to remedy environmental problems).

10) Some of these measures (e.g. improve infrastructure) are aimed at reducing costs, even if this means bringing in more tourists. In effect, therefore, they represent "more of the same" and serve merely to postpone the bottom-line consequences of the inevitable change of model for private-sector tourism enterprises. ${ }^{21}$

11) Other measures (e.g. environmental protection) are aimed at minimizing the longerterm costs. Again, they do not represent a change of model; they simply mitigate externalities on the assumption that tourism can be both economically viable and environmentally sustainable.

12) Yet others are designed to differentiate the product and exploit market niches by at least partly developing a different model of tourism, one that has greater economic (revenue-generating) potential and lower environmental and social costs, once again on the assumption that this other model will be viable. ${ }^{22}$

13) The attitude of tourism entrepreneurs (especially hotel owners) toward real estate development is ambiguous, ${ }^{23}$ as it generates significant costs and benefits, which are unequally shared. A majority would probably argue for strict restrictions on new development.

14) In any case, any changes to the model would have to be applied across the board: in all parts of Spain, in competing countries and in other industries. There would be no point, for example, in imposing drastic anti-pollution measures on the tourism industry if similar measures were not also imposed on other industries and services.

15) Unless the changes in the model generate an acceptable stream of net income, the industry evidently takes it for granted that compensatory measures will be needed to win the acceptance of those adversely affected and to correct the negative

\footnotetext{
${ }^{20}$ In an environment of growing global competition, this argument is sometimes also justified by the need to allow investors to recover their investments. On the other hand, the prospect of a change of policy may accelerate the negative effects: if the government is planning to impose restrictions on urban development, for example, the interested parties (landowners, developers and builders) will probably try to speed up any developments already under way.

${ }^{21}$ The measures may have some positive environmental effects (less road congestion, shorter trips, energy saving), but also some negative ones (arrival of more tourists, more conflict over resource use).

${ }^{22}$ Viable, that is, from the economic, environmental, social and cultural point of view. This assumes, for example, that the growth of rural tourism is compatible with environmental balance; that the decentralization of tourist areas toward ski or golf resorts does not harm the environment; and that cities can accommodate larger numbers of visitors without damaging their historical and cultural heritage.

${ }^{23}$ Real estate investment has been a flourishing activity in the years of the building boom and has attracted the capital of many tourism entrepreneurs, but also of many other people.
} 
distributive effects (e.g., unemployment insurance for those who lose their jobs, ${ }^{24}$ subsidies for corporate restructuring, transfer of industries from other areas, etc.).

16) The sector still has faith in the incentives created by existing tourism policies (promotion of Spain's image abroad, infrastructure development, tax incentives, etc.), as they benefit a wide range of players.

\section{Social Responsibility in the Tourism Industry}

As we pointed out earlier, tourism has a significant environmental, social and human impact. So it is hardly surprising that the concept of corporate social responsibility (CSR) should have been brought to bear, especially in the context of sustainable or environmentally responsible tourism (Ayuso and Fullana, 2002; Bengoechea et al., 2006; Bramwell and Lane, 1993; Hall and Brown, 2006; Hunter and Green, 1995; Müller, 1994; Welford et al., 1999).

CSR is not a management technique or set of practices that companies can choose to embrace, or that society imposes on them. First and foremost, it is an ethical concept, namely the concept that all companies are responsible for their decisions and the results of those decisions, however uncertain and diffuse. This is related to the concept of responsibility itself, i.e. the notion that every person is responsible for the decisions he or she makes freely and consciously, although the degree of a person's responsibility will obviously vary from case to case (Argandoña and Hoivik, 2009).

CSR is a company's understanding of the role it plays in society, not in the abstract but based on its current situation, the environment in which it operates, the values it upholds and its awareness of the intended and unintended consequences of its actions. Based on that understanding, every company will have certain responsibilities toward society that it acknowledges and is willing to assume, in dialogue with stakeholders and other social agents. Those will be its corporate social responsibilities. In a manner of speaking, the company gradually becomes more aware of its responsibilities to society and its stakeholders, based on its own experiences and what its stakeholders and society expect of it.

To whom is a company responsible? First, to itself and its internal stakeholders (owners, managers and employees), because if it is true that a company is a community of persons, the company must answer to that community for what it is and does. In other words, CSR is a joint and shared responsibility within the organization (Argandoña, 2008a). Second, a company is responsible to its external stakeholders, i.e. the individuals and population groups affected by its activity, including customers and suppliers, other players in the company's value chain, local communities, society in general and future generations (this leads us to the dimensions of responsiveness and accountability). CSR is thus a dynamic process that evolves over time, in line with changes in the environment, shifting external demand and the moral maturity of the organization itself (Argandoña and Hoivik, 2009).

Tourism companies therefore clearly bear some responsibility for the decisions they have made and the human, social and environmental consequences of those decisions (including overdevelopment, to which they have contributed). This is neither to say that all tourism

\footnotetext{
${ }^{24}$ A large percentage of the tourism workforce are immigrants on temporary contracts.
} 
companies bear the same responsibility, nor that they are the only ones responsible. As we said earlier, many tourism companies are "hostage" to a model they did not create and cannot easily escape.

Each company, once it has acknowledged its responsibilities, must decide what it can do. For this purpose it has at its disposal all the traditional tools of CSR: codes of conduct and best practice, ecolabels and awards, ethical, social and environmental management systems (Argandoña, 2004), environmental performance indicators, staff training policies, transparency and truthfulness in reporting to customers, social responsibility and sustainability reports, etc. (Ayuso, 2007; Pérez, 2004). A growing number of companies have adopted measures such as these and made them an integral part of their strategy and day-to-day activity (see Exhibit 2 for a sample of CSR initiatives in the Spanish tourism industry).

What matters, in each case, is what the individual company can and should do, which inevitably will be limited, especially for SMEs (Argandoña, 2008b). This is an important task, driven by companies' desire to live up to their responsibilities. It helps create a climate within companies in which people accept those responsibilities and are willing to work to fulfill them. Needless to say, individual companies cannot be expected to solve the big problems, such as environmental degradation or overdevelopment. As we indicated, externalities such as these make single-player solutions unfeasible.

Does this mean that CSR does not apply in such cases? No. Every company bears a share of responsibility, which it must assume, however small. At this level, however, we are talking about the social responsibility of the industry as a whole, a responsibility that extends to each subsector and geographical area and that is the sum of the responsibilities of all the companies in the industry, plus the external effects they have on each other, including when they interact with other agents such as consumer associations, governments, international bodies and nongovernmental organizations. We could describe it as a "chain" of social responsibilities, from personal responsibilities (of individual owners, managers and employees) to company or group responsibilities, subsector responsibilities and, finally, industry responsibilities, all this within the scope of a particular city, region, country or even larger geographical area. Each agent in this chain must assess its own responsibilities, look for solutions that lie within its reach, work with other agents where necessary and refer to a higher level any responsibilities it cannot resolve for itself ${ }^{25}$ (and such referral is not an abdication of responsibility, but an exercise of it).

\section{The CSR of tourism companies}

To sum up, how can CSR help solve the problems of companies or groups of companies operating in the tourism industry? Here are a few suggestions as to what companies can do:

1) Acknowledge their responsibilities and be ready to meet them, even if the benefits seem likely to be minimal.

\footnotetext{
${ }^{25}$ In Spain there are no tourism industry associations that make CSR their primary concern. The closest is Exceltur Alianza para la Excelencia Turística, an association of large tourism companies and groups whose purpose is to promote the industry and make it more competitive. It includes hotel groups, transportation companies, tour operators and travel agencies, amusement parks, financial service companies, foodservice companies and tourist hospitals (cf. www.exceltur.org). As regards CSR, see Exceltur (2003).
} 
2) Instill a culture of responsibility by setting an example and training internal and external stakeholders.

3) Collaborate with other stakeholders, including NGOs, local governments, experts, etc., rather than trying to do everything on their own.

4) Build on the experience of other companies in the industry and outside it (there is no need to reinvent the wheel).

5) Take a prudent approach to CSR. There is no need to do everything at once (although this should not become an excuse for doing nothing).

6) Be realistic. CSR has costs that companies cannot always afford, especially small companies operating in very competitive markets. Again, however, this is not an excuse for doing nothing.

7) CSR always requires long-term vision, which is something companies need to develop.

\section{The CSR of the Tourism Industry}

There are, however, situations where a company is aware of its responsibilities but is unable to exercise them, situations such as those described earlier, in which externalities are significant, decisions are blocked by players held "hostage" to the model, perverse incentives prevail, or there is no easy alternative to traditional tourism. In such situations, some kind of collective action is required, as action by individual companies or groups is ineffective (with the possible exception of very large groups that have considerable market power).

Yet even collective action may face obstacles and prove ineffective. Essentially, no firm wants other firms to degrade the environment, damage the industry's international image or cause serious environmental harm. Yet if rules are established for the group as a whole, each member of the group stands to gain by acting against them. For this reason, it is very difficult to define, let alone enforce, any collective rules. This is a variant of the "tragedy of the commons:" a situation in which multiple individuals, acting independently and solely and rationally consulting their own self-interest, will ultimately deplete a shared limited resource even when it is clear that it is not in anyone's long-term interest for this to happen (Hardin, 1968).

The solutions to the "tragedy of the commons" problem are mainly two. One is the privatization of all the resources, with a well-defined system of property rights: but this is not viable in many countries where the constitution lays down that several assets should be common property - and its implementation would create a lot of problems.

The alternative solution is to ascribe to the government the design and application of effective policies to internalize the externalities: comprehensive taxes, subsidies and regulations. But we have applied these policies in the past, and the results were unsatisfactory. As we mentioned earlier, governments may not be in a position to act adequately, either because they lack power or because they are hostage to the model they are supposed to correct, or have incentives other than the common good, or do not act impartially. In any case, the role of the government is evident, but it could need the support of other agents: the third sector and, of course, industry. In cases such as these, a solution to the problem may come from the social responsibility of the tourism industry, at the initiative of industry associations or individual companies that 
recognize the need for a more resolute response to the exhaustion of the existing model. The following should not be taken as a complete action program but merely as suggestions, based on CSR theory.

Stakeholder dialogue (Svendsen, 1998) is a particularly appropriate means of addressing problems that are beyond the scope of any one company or group. In matters with such farreaching implications for society, a wide range of stakeholders needs to be considered. Merely brokering an agreement between hotel owners, real estate developers and local councils will not be enough, as many other stakeholder groups that should have a say will have been ignored. ${ }^{26}$ Broad-based stakeholder dialogue can loosen the grip of tightly knit interest groups and unblock negotiations.

Any attempt to rethink tourism should not ignore the rest of the economy. "Overall harmonious growth of society can only be achieved if the real interests of all the stakeholder groups that must live together in society are reconciled (...) [with the aim of] making tourism planning conducted, as it should be, with the participation of all those groups - a privileged opportunity to jointly map out the future we consider desirable for all. The second step is to collectively determine what must be done in order to reach the desired situation and decide what role tourism should play in building this common project" (Bernadas, 2008, pp. 84-85). This view is probably constructivist and the task it sets is clearly beyond the scope of the dialogue proposed here. But at least it acknowledges that tourism should not be treated in isolation from the society in which it is embedded.

All stakeholders (broadly defined) must be heard, but not all their demands and expectations need be met. It is also important to put "names and faces" to the stakeholders: they are not anonymous groups but people with specific interests and concerns (McVea, 2005). Stakeholder dialogue must be open and unlimited, especially in the early stages. The aim, initially, should be to gather information and hear everybody's point of view, assess the situation and propose a solution. The timetable for implementing the difficult decisions must be realistic. A new model of tourism development cannot be built in a few months; but the goal must be clear from day one. Short-term difficulties - for example, the problems of the current crisis - should not be allowed to interfere with long-term issues.

Dialogue should lead to the formulation and implementation of a policy, "a process of quality change resulting from political initiative that includes the indispensable participation of the local population and that adapts the institutional and legal framework, and the planning and management tools" (Vera and Ivars, 2004, pp. 180-181). And this is a task for the various levels of government.

Those who promote and drive something as important as a transformation of the tourism industry (policymakers, if possible, but also respected industry figures and experts) must show leadership. Moreover, stakeholder collaboration must not be confined to dialogue, but must also include execution, especially public-private collaboration. And in complex matters such as this, mechanisms must be put in place to monitor progress and redefine objectives.

\footnotetext{
${ }^{26}$ Some agreements between very specific interest groups arouse suspicion: "Plan Dia [a tourism planning document produced by the government of Andalusia] is described as a 'consensual' plan (p. 25), which, in itself, may be thought enough to set alarm bells ringing” (Barke and Towner, 2004, p. 160).
} 


\section{Conclusions}

The Spanish model of tourism, which yielded such positive results in the past, has now, in many people's opinion, exhausted its potential. Within the industry, commentators point to economic signs (decline in demand and spending per tourist) that a change of model is needed. Attention outside the industry tends to focus on the negative environmental and social impact. It is generally agreed that certain kinds of tourism have been overdeveloped: hotel complexes, apartments and second homes for residents and non-residents have proliferated, resulting in unsightly beaches, second-rate services, traffic congestion and environmental degradation, threatening the very future of tourism.

The Spanish model of tourism has changed continuously and yet retains some of its original characteristics, which is why it has exhausted its potential. In this paper, we have discussed some of the reasons for the model's longevity. They are mainly related with investments already made, incentives that have been established, the symbiosis of tourism and real estate, and the mistakes and failures of the policies implemented over the last fifty years. We have also discussed the attitudes and complicities among the industry players that prevent any departure from the pattern of the past. The externalities (which have made the model unviable) cannot be overcome by companies acting individually (though many have done their best) but require collective action, which must be backed by government policy. Yet even collective action has failed and tourism policy has failed to resolutely address the problems arising from the established model.

We conclude with an appeal to the concept of corporate social responsibility. We explain the nature of tourism companies' responsibilities, how these companies can meet their responsibilities, and how the theoretical underpinnings and practical recommendations of CSR can help overcome the exhaustion of the inherited model of tourism, including the overdevelopment of beach tourism. 


\section{Exhibit 1}

International tourism in Spain in 2008

Visitor arrivals: 99.1 million

Tourists (who stayed at least one night): 57.3 million

Maximum number of arrivals: 58.7 million in 2007

Seasonality: 35\% of arrivals in July, August and September

Origin: 93.5\% from Europe

60\% from United Kingdom, Germany and France

Means of arrival: $77.5 \%$ by air

$48 \%$ with low-cost carriers

Destination: 84.3\%, Mediterranean coast, Balearic Islands and Canaries

91\%, Catalonia, Balearics, Canaries, Andalusia, Valencian Community and Madrid

Accommodation: 64\% in hotels

$8 \%$ in rental accommodation

7.6\% in own accommodation (22.1\% in Murcia, 19.1\% in Valencian Community)

Organization of trip: 69.3\% without tourist package

54\% used the Internet to organize one or more stages of the trip

Tourist profile: $50 \%$ with university degree

65\% medium income level, 23\% high income

Loyalty: 84\% had visited Spain at least once before

$37 \%$, ten times or more

Reason for trip: 81.6\%, leisure or vacation

97.2\% in the Canaries, $84.1 \%$ in Andalusia

Satisfaction with trip: 8.4 out of 10 .

Total expenditure by foreign tourists: 51,897 million euros

907 euros per person, 95 euros per day

Average duration of stay: 9.5 nights

Employment (accommodation, transportation and foodservice): 2,623,389 people

$21.2 \%$ non-nationals

Supply of collective accommodation: 3.1 million beds

17,988 hotel establishments, 1,682,559 beds

163,108 tourist apartments (legally registered), 575,623 beds

12,321 rural accommodations, 111,833 beds

1,228 camp sites, 765,140 beds

$73 \%$ of the total beds located on the Mediterranean coast and islands

National income from tourism: 41,900.9 million euros

Net income from tourism: 28,066.6 million euros

Share of GDP: 10.7\% (2007) 
Golf courses: 398 (Royal Spanish Golf Federation)

Cruises: 3,612 cruises

5.8 million passengers

Marinas: 355 (October 2009) (Spanish Federation of Marinas \& Yacht Harbors Associations) 126,693 berths

Amusement parks: 140 (April 2008)

Zoos, aquariums and nature parks: 78

Water parks: 53

Theme parks: 5

Amusement parks: 4

Source: Instituto de Estudios Turísticos (2009a, b y c). 


\section{Exhibit 2}

Examples of social responsibility practices from the tourism sector by Lena Strandberg ${ }^{27}$

In tourism, a company organizes its production factors (mainly labor) to deliver a service to a customer in a particular physical environment and community, on which the service has certain mainly environmental impacts. We shall use this simple description to classify the following examples of social responsibility practices among tourism companies around these four areas, customers, employees, environment and communities.

If these are the theoretical areas of responsibility for companies, what are the practical responses, i.e. what are individual companies doing to fulfill their responsibility and reduce the adverse impact of their activities? In this exhibit, we describe some of the CSR activities that Spanish tourism companies are including in their business. As hotels have been the first to tackle these issues, while in other sectors, such as cruises and yachts, the responsibility is still relatively new, the examples given here come mainly from hotel chains.

\section{Customers}

Tourists are the people who create the business opportunity and companies have a responsibility to serve them in an ethical way. The Global Code of Ethics for Tourism states the responsibilities of companies toward their customers, which include providing quality service and honest and objective information. ${ }^{28}$

Information. Customers should be informed about the price and quality of the product or service and exactly what is included in it. Even before customers arrive at the place of destination, tourism companies must show responsibility in their marketing strategies, including pricing, distribution and communication. This means, for example, no hidden charges and no false promises (an "ocean view," for example, or a particular standard of accommodation).

Quality. There are various ways of monitoring service quality, including customer satisfaction surveys, assessments and certifications. In order to achieve and guarantee the quality of the services offered, Grupo Barceló has established a quality system based on four areas of intervention: implementation of quality manuals, training, surveys and administration of complaints and suggestions. The quality manuals refer to both services and facilities, and implementation of the quality standards is combined with training the staff who are to enforce the standards. The surveys are performed both by the hotels themselves combined with visits by "mystery guests," in order to assess clients' satisfaction. ${ }^{29}$ The state-owned hotel chain Paradores has received the "Q-Mark for Tourism Quality" certification from the Spanish Institute for Tourism Quality (Instituto para la Calidad Turística Española, ICTE). Q-Mark certification guarantees the quality of the products and services offered and is developed by

\footnotetext{
${ }^{27}$ Lena Strandberg is Researcher, "la Caixa” Chair of Corporate Social Responsibility and Corporate Governance, IESE Business School.

${ }^{28}$ Global Code of Ethics for Tourism. www.world-tourism.org.

${ }^{29}$ Grupo Barceló: http://www.barcelo.com/Group/es-ES/CorporateInformation/Quality/QualityPrograms.htm.
} 
each hotel in collaboration with the ICTE and an auditing firm. ${ }^{30}$ Another award is the ISO 9001 certification received by the shipping company Acciona Trasmediterránea, amongst others. ${ }^{31}$

Accessibility. Accessibility of the place of destination is important in order to serve tourists with different preferences and needs. According to the Global Code of Ethics for Tourism, senior tourism and tourism for people with disabilities should be encouraged and facilitated. ${ }^{32}$ The Paradores chain has developed an accessibility plan, which is being implemented in all the chain's hotels. ${ }^{33}$

Informing and awareness raising. A number of hotels are making efforts to influence tourist behavior by educating and informing tourists about their impact on the environment. $\mathrm{NH}$ Hoteles has launched a campaign to raise environmental awareness by posting messages in rooms and bathrooms inviting guests to consider their impact on the environment. ${ }^{34}$ The Port of Barcelona offers environmental consulting services to customers and businesses operating in the port. ${ }^{35}$

The car rental company Avis España, offers the possibility for their customers to support carbon emissions reduction programs when booking the rental cars online through the company's website. Additionally, Avis España provides the customers with advice on how to drive in a more environmental friendly fashion. ${ }^{36}$ Another company in the same business, National Atesa, organizes road safety and security campaigns to inform the customers of the need to drive responsibly. ${ }^{37}$

\section{Employees}

To fulfill their responsibility to customers, companies need to show responsibility to the people who deliver the service, i.e. their employees. Creating and maintaining customer satisfaction depends on employees and their capabilities, competence and willingness to provide highquality service.

The tourism sector has certain special characteristics that affect the nature of the jobs it offers, notably a relatively uneducated workforce, low wages, few or no fringe benefits, seasonality, and a division between local or immigrant labor in lower level jobs and outsiders in higher level technical and managerial positions. Given these characteristics, employers in the sector have certain important responsibilities.

Initial and continuous training. Given the lack of education among the workforce, initial and ongoing education and vocational training is important. Some hotels have combined their regular activities with education in hotel management. NH Hoteles has founded NH University, which runs training courses for employees, both on-site and online. The company has also created a certification program, which sets out all the courses a employee must complete in the

\footnotetext{
${ }^{30}$ ICTE. http://www.icte.es/marca/beneficios.htm

${ }^{31}$ Acciona Trasmediterránea. $\mathrm{http}$ ://www.trasmediterranea.es/index.asp?section=plain\&module=calidad\&lang=UK

32 Global Code of Ethics for Tourism. www.world-tourism.org.

33 Paradores Annual Report 2008 and Universal Accessibility Manual for Hotels, 2007.

${ }^{34} \mathrm{NH}$ Hoteles homepage: $\underline{\mathrm{http}}$ ://corporate-information.nh-hotels.com/wda/esp/clientes.jsp\#sensibilizacion_clientes.

${ }^{35}$ Port de Barcelona: www.portdebarcelona.es.

${ }^{36}$ Avis España: http://www.avis.es/MedioAmbiente/Avis-y-el-Medioambiente.

${ }^{37}$ National Atesa: http://www.atesa.es/webcorporativa/contenido/categoria.aspx? cat=6\&sub=0\&idioma=es-ES.
} 
form of a personal training itinerary. Facilities include an on-line training platform and knowledge management, where employees can find courses and other information that will enable them to continue learning.

Riu Hotels and Resorts offer their employees initial education when entering the company, training to support career development, continuous training to enable adaption to new demands from the customers and new technologies, as well as language training. ${ }^{38}$

Health and safety. A variety of practices have been adopted to promote employee health and safety. Paradores carries out regular assessments to identify general risks and individual assessments for each position. Sol Meliá annually conducts a survey in order to assess coworker satisfaction regarding the work environment. ${ }^{39}$

Diversity. Women are overrepresented in the tourism workforce, accounting for 70 percent of the total, and a majority of tourism workers are young (Dobbs and Joppe, 2005). To manage diversity, NH Hoteles created in 2008 the position of Diversity Manager, tasked with promoting integration, coexistence and tolerance. The company is currently developing an Equal Opportunities Plan in negotiation with the major unions. ${ }^{40}$ The Playa Senator hotel chain has created a program in order to work for equal opportunities for women, as well as a program offering internships to women who have been victims of abuse. ${ }^{41}$

Some hotels are taking steps to include disadvantaged groups in their workforce. The Grupo Barceló (including the hotel chain and the travel agency) has launched an integration program and works with non-profits to integrate excluded groups, such as drug addicts and battered women, in the company. ${ }^{42}$ The Hoteles Fiesta chain has a policy of including disabled and disadvantaged people and groups at risk of exclusion in its workforce. ${ }^{43}$

\section{Environment}

The environment plays a key role in the tourism industry, as it is often one of the main attractions for tourists. It is also a limited resource that is affected by the activities of tourists and tourism businesses alike. Environmental consequences include over-utilization of natural resources, especially water; inefficient use of energy; and inadequate waste management.

Energy and water saving. The hospitality industry has started to implement systems to reduce energy and water consumption and improve waste handling. Riu Hotels \& Resorts has reduced its energy consumption by switching to low-energy light bulbs. Most hotels now have efficient heating and air conditioning, with a system to automatically turn off the air conditioning or heating when a customer opens the balcony. Almost all rooms have a switch or card that turns off the electricity when customers leave the room to avoid wastage. ${ }^{44}$ Playa Senator is working to reduce their use of water by monitoring daily use but also by applying measures such as

\footnotetext{
${ }^{38}$ Riu Hotels and Resorts: http://www.riu.com/es/Acerca_de_RIU/rrhh.jsp.

${ }^{39}$ Sol Meliá, Memoria 2008.

${ }^{40}$ NH Hoteles. http://corporate-information.nh-hotels.com/wda/eng/employees.jsp\#gestion_diversidad.

${ }^{41}$ Exceltur; Alianza para la excelencia. Playa Senator, Informe Anual 2007.

http://www.playasenator.com/db/noticias/public/form_detalle_noticia.php?c_noticia=16\&idioma=es\&tipo=.

42 http://www.barcelo.com/Group/en-GB/CorporateInformation/Philosophy.htm.

${ }^{43}$ Exceltur, 2003. Acción social en el sector turístico.

${ }^{44}$ http://www.riu.com/es/Acerca_de_RIU/medio_ambiente/index.jsp.
} 
recovery of filtered water from swimming pools and considering the layout and design of the hotels' gardens. ${ }^{45}$ As of 2000, Grupo Iberostar applies environmental criteria in their policies when selecting new suppliers and incorporating new complexes. ${ }^{46}$

Coastal areas. For tourism in coastal areas, management of port environments and water quality is vital. The Port of Barcelona manages its impact on the environment through a plan to prevent, protect against and investigate oil spills, in line with the MARPOL Convention. ${ }^{47}$ It also works with port visitors, offering consulting services on environmental matters, including licenses, ISO 14000 and emission controls. The Port of Ginesta, south of Barcelona, has developed an environmental plan based on ISO 14001 and EMAS which guides all the work it does, from planning through to implementation, monitoring and final assessment. The plan includes water and wastewater management, energy and waste management, supplier evaluation and employee training.

Boats visiting ports also have an environmental responsibility. In the cruise line and cruise ship sector, environmental and sustainability issues have recently started to receive more attention. Given their size and activities, cruise ships generate large quantities of waste and wastewater. To reduce the impact, over one-third of Carnival Corporation's cruise ships now have water purification systems to treat the black and grey water they produce ${ }^{48}$ Norwegian Cruise Line is a pioneer in the recycling of used lube oil and routinely recycles plastics, aluminum, steel, oil sludge and a wide variety of consumer products. ${ }^{49}$ In 2008, the cruise line Holland America Line was rewarded with the Virgin Holidays Responsible Tourism Award for their reduction of dockside emissions by 20\%, development and implementation of an "Avoiding Whale Strikes" training program, a 50\% increase in recycling and the introduction of new scrubber technology. ${ }^{50}$

\section{Communities}

Tourism involves people traveling to another place and entering different surroundings. It therefore has economic and socio-cultural impacts on the local or host community. Economic impacts include job creation, tax revenues, wages, etc. and also adverse effects, such as higher prices for food and transportation and higher land prices. The socio-cultural impacts are often negative, and social, economic and political developments can crucially affect the relationship between residents and tourists. Cultural differences, including different value systems, religious beliefs, lifestyles and traditions, influence the meeting of the two groups and its consequences (Payne and Dimanche, 1996).

Philanthropy. Several hotel chains and cruise lines are working with fundraising projects in the destination countries or ports they visit. The Sol Meliá hotel chain and the Grupo Barceló, to name two, adhere to the ECPAT Code of Conduct in their fight against sexual tourism involving

\footnotetext{
${ }^{45}$ Playa Senator, Informe Anual 2007. http://www.playasenator.com/db/noticias/public/form_detalle_noticia.php?c_noticia=16\&idioma=es\&tipo=. 
children. ${ }^{51}$ Hoteles Husa has developed a program offering scholarships to employees' children, while Hoteles Hesperia offers cut-price accommodation for NGOs and foundations. ${ }^{52}$ Norwegian Cruise Line has a donation program supporting charity organizations around the world, as well as a program focused on Hawaii. ${ }^{53}$ Carnival Corporation works with employee fundraisers and hands-on volunteer service initiatives, cash and cruise donations. ${ }^{54}$

The travel agency Globalia Corporación Empresarial and Viva Tours organize campaigns among their employees to give blood, collect clothes and toys, etc. ${ }^{55}$ Viva Tours and Viajes Barcelo are negotiating agreements to enable employees to give classes at universities and business schools.

Associations. Although the tourism industry's social responsibility has not been emphasized by industry associations in Spain, there are a few organizations that conduct certain activities. The Spanish Confederation for Hotels and Tourist Lodgings (Confederación Española de Hoteles y Alojamientos Turísticos, CEHAT) aims to improve working conditions in hotels through different measures such as education and training as well as occupational risk prevention. ${ }^{56}$ Exceltur, a non-profit organization formed by several tourist corporations, has conducted a study of the social responsibility activities performed by Spanish and international tourist companies. $^{57}$

\footnotetext{
51 The Code. http://www.thecode.org/.

${ }^{52}$ Exceltur, 2003. Acción social en el sector turístico.

${ }^{53}$ NCL. http://www.ncl.com/nclweb/cruiser/cmsPages.html?pageId=CorpGiving.

${ }^{54}$ Carnival Corporation. http://phx.corporate-ir.net/phoenix.zhtml?c=140690\&p=irol-govhighlights.

${ }^{55}$ Exceltur, 2003. Acción social en el sector turístico.

${ }^{56}$ CEHAT: http://www.cehat.com/frontend/cehat/AREAS-DE-TRABAJO-vn2616-vst210.

${ }^{57}$ Exceltur: http://www.exceltur.org/excel01/contenido/portal/conozca_que_es.aspx.
} 


\section{References}

Agarwal, S. (2002), "Restructuring seaside tourism: The resort lifecycle," Annals of Tourism Research, 29 (1), pp. 25-55.

Argandoña, A. (2004), "On ethical, social and environmental management systems," Journal of Business Ethics, 51 (1), pp. 41-52.

Argandoña, A. (2008a), “The ethical dimension of Corporate Social Responsibility," presented at the 2008 EBEN-UK Annual Conference, Cambridge, April 1-2.

Argandoña, A. (2008b), "La responsabilidad social de las empresas pequeñas y medianas," Cuadernos de la Cátedra "la Caixa" de Responsabilidad Social de la Empresa y Gobierno Corporativo, IESE, 1, June.

Argandoña, A. and H. Hoivik (2009), "Corporate Social Responsibility: One size does not fit all. Collecting evidence from Europe,” Journal of Business Ethics, forthcoming.

Ayuso, S. (2007), "Comparing voluntary policy instruments for sustainable tourism: The experience of the Spanish hotel sector," Journal of Sustainable Tourism, 15 (2), pp. 144-159.

Ayuso, S. and P. Fullana (2002), Turismo sostenible, Barcelona: Rubes.

International Bank for Reconstruction and Development (1962), "El desarrollo económico de España," Madrid: Imprenta del Boletín Oficial del Estado.

Barke, M. and J. Towner (2004), "Learning from experience? Progress towards a sustainable future for tourism in the Central and Eastern Andalusian littoral," in B. Bramwell, ed., "Coastal Mass Tourism Diversification and Sustainable Development in Southern Europe," Clevedon, UK: Channel View Publications, pp. 157-175.

Bernadas, J. M. (2008), “Quin turisme volem?,” Metròpolis, June-September, pp. 84-85.

Bengoechea, A., M. Magadán, and J. Rivas (2006), “Actividad turística y medio ambiente," Oviedo: Septem Ediciones.

Bramwell, B. and B. Lane (1993), "Sustainable tourism: An evolving global approach," Journal of Sustainable Tourism, 1 (1), pp. 1-5.

Casado, M. A. (2004), "Second homes in Spain," in C. M. Hall and D. K. Muller (eds.), "Tourism, Mobility, and Second Homes: Between Elite Landscape and Common Ground," Clevedon, UK: Channel View Publications, pp. 215-232.

Consejo Español de Turismo (2006), "Plan de Turismo Español Horizonte 2020," Madrid: Consejo Español de Turismo.

Cortina, F., A. Martínez, and B. Varela (2002), “Aproximación a la investigación del alojamiento privado de uso turístico,” Estudios Turísticos, 151, pp. 87-97.

Díaz, F. (2008), “La sostenibilitat només somiada,” Metrópolis, June-September, pp. 63-65. 
Dobbs, R. and M. Joppe (2005), "CSR in the Tourism Industry? The Status of and Potential for Certification, Codes of Conduct and Guidelines," Study prepared for the CSR Practice Foreign Investment Advisory Service Investment Climate Department.

Exceltur (2003), “Acción social en el sector turístico,” Madrid: Exceltur and Fundación Empresa y Sociedad.

Flognfeldt, T. (2002), "Second homes ownership. A sustainable semi-migration," in C. M. Hall and A. M. Williams (eds.), "Tourism and Migration, New Relationships between Production and Consumption,” Dordrecht: Kluwer, pp. 187-203.

García-Canclini, N. (2005), “Paranoics versus utilitaristes,” Nexus, 35, winter 2005-2006, pp. 16-19.

Gustafson, P. (2001), "Retirement migration and transnational lifestyles," Ageing and Society, 21 (4), pp. 371-394.

Gustafson, P. (2002), “Tourism and seasonal retirement migration," Annals of Tourism Research, 29 (4), pp. 899-918.

Hall, D. and F. Brown (2006), “Tourism and Welfare: Ethics, Responsibility, and Sustained Wellbeing," Wallingford, UK: CABI Publishing.

Hardin, G. (1968), "The tragedy of the commons," Science, 162, pp. 1243-1248.

Huber, A. (2000), "La migración internacional de tercera edad: El caso de los jubilados europeos en la Costa Blanca (Alicante) y los problemas de plazas en residencias," presented at the II Congreso sobre la Inmigración en España, Madrid, Universidad de Comillas, October 5-7.

Hunter, C. and H. Green (1995), "Tourism and the Environment: A Sustainable Relationship?," London: Routledge.

Instituto de Estudios Turísticos (2009a), "EGATUR - Encuesta de Gasto Turístico. Informe anual 2009," Madrid: Instituto de Estudios Turísticos.

Instituto de Estudios Turísticos (2009b), "FRONTUR - Movimientos Turísticos en Fronteras. Informe anual 2009," Madrid: Instituto de Estudios Turísticos.

Instituto de Estudios Turísticos (2009c), "Resultados de la Actividad Turística en España. Informe 2008," Madrid: Instituto de Estudios Turísticos.

Iribas, J. M. (2000), “Benidorm, manual de uso," in MVRDV, “Costa Ibérica. Hacia la ciudad del ocio," Barcelona: Actar.

Mantecón, A. (2005), "La construcción social de la experiencia turística: el caso de los anfitriones," in T. Mazón and A. Aledo (eds.), "Turismo residencial y cambio social. Nuevas perspectivas teóricas y empíricas,” Alicante: Aguaclara, pp. 391-410.

Mantecón, A. (2008), "Procesos de urbanización turística. Aproximación cualitativa al contexto ideológico,” Papers, 89, pp. 127-144.

Mazón, T. (2001), “Sociología del turismo,” Madrid: Editorial Centro de Estudios Ramón Areces.

Mazón, T. (2002), "Los problemas del turismo inmobiliario en el litoral alicantino," presented at the I Ciclo de conferencias "Sociedad y medio ambiente, temas de nuestro tiempo," Altea, Fundación Ciencias Sociales y Mundo Mediterráneo and Fundación Diversidad, November 7-9. 
Mazón, T. and A. Aledo (2005), "El dilema del turismo residencial: ¿turismo o desarrollo inmobiliario?," in T. Mazón and A. Aledo (eds.), "Turismo residencial y cambio social. Nuevas perspectivas teóricas y empíricas,” Alicante: Aguaclara, pp. 13-30.

McVea, J. F. (2005), “A names-and-faces approach to stakeholder management,” Journal of Management Inquiry, 14 (1), pp. 57-69.

Moreno, A. (2007), "Historia del turismo en España en el siglo XX,” Madrid: Síntesis.

Müller, H. (1994), "The thorny path to sustainable tourism development," Journal of Sustainable Tourism, 2 (3), pp. 131-136.

Oliver, J. (2005), "Barcelona: vers un nou model turístic?," Nexus, 35, winter 2005-2006, pp. 148-159.

O'Reilly, K. (2000), “The British of the Costa del Sol. Transnational Identities and Local Communities," London: Routledge.

Payne, D. and F. Dimanche (1996), "Towards a Code of conduct for the tourism industry: an ethics model," Journal of Business Ethics, 15, pp. 997-1007.

Pellejero, C. (2004), "Iniciativas y participación del sector público español en el desarrollo del turismo," Papeles de Economía Española, 102, pp. 49-66.

Pérez, M. (2004), “Manual del turismo sostenible,” Madrid: Ediciones Mundi-Prensa.

Rivas, J. (2009), “Estructura y economía del mercado turístico,” Oviedo: Septem Ediciones.

Robledo, M. A. and J. Batle (2002), "Re-planning for tourism in a mature destination: A note on Mallorca," in R. N. Voase (ed.), "Tourism in Western Europe: A Collection of Case Histories," Wallingford, UK: CABI Publishing.

Rodríguez, V., G. Fernández and F. Rojo (2000), “Impactos de la inmigración internacional de retirados en las costas españolas,” OFRIM Suplementos, 7, pp. 117-138.

Salvà, P. (2005), "Procesos, pautas y tendencias del turismo residencial en las Islas Baleares: ¿inmigrantes de lujo o turistas de larga estancia?," in T. Mazón and A. Aledo (eds.), "Turismo residencial y cambio social. Nuevas perspectivas teóricas y empíricas,” Alicante: Aguaclara, pp. 281-302.

Shaw, G. and A. M. Williams (2004), “Tourism and Tourism Spaces,” London: Sage Publications.

Singh, T. V. (2005), "New Horizons in Tourism. Strange Experiences and Stranger Practices," Wallingford, UK: CABI Publishing.

Svendsen, A. (1998), "The Stakeholder Strategy: Profiting from Collaborative Business Relationships," San Francisco, CA: Berrett-Kohehler Publishers.

Vera, J. F. (1994), "El modelo turístico del Mediterráneo español: agotamiento y estrategias de reestructuración," Papers de Turisme, 14-15, pp. 131-148.

Vera, J. F. and J. A. Ivars (2004), "Measuring sustainability in a mass tourist destination: Pressures, perceptions and policy responses in Torrevieja, Spain," in B. Bramwell (ed.), "Coastal Mass Tourism Diversification and Sustainable Development in Southern Europe," Clevedon, UK: Channel View Publications, pp. 176-199. 
Welford, R., B. Ytterhus, and J. Eligh (1999), "Tourism and sustainable development: An analysis of policy and guidelines for managing provision and consumption," Sustainable Development, 7 (4), pp. 165-177.

\section{Websites}

Acciona Trasmediterránea

Link: http://www.trasmediterranea.es/ December, 2009.

Avis España

Link: http://www.avis.es/ January, 2010.

Barceló Grupo.

Link: http://www.barcelo.com/ December, 2009.

Carnival Corporation

Link: http://phx.corporate-ir.net/ December, 2009.

CEHAT

Link: http://www.cehat.com/ January 2010.

Exceltur

Link: http://www.exceltur.org/ January 2010.

Fundación Barceló

Link: http://www.barcelo.com/ December, 2009.

Global Code of Ethics for Tourism

Link: www.world-tourism.org/ December, 2009.

Instituto para la Calidad Turística Española

Link: http://www.icte.es/ December, 2009.

National Atesa

Link: http://www.atesa.es/ January, 2010.

NH Hoteles.

Link: http://corporate-information.nh-hotels.com/ December, 2009.

Norwegian Cruise Line

Link: http://www.ncl.com/ December, 2009.

Paradores

Link: http://www.parador.es/ December, 2009.

Port de Barcelona

Link: www.portdebarcelona.es/ December, 2009.

ReponsibleTravel.com.

Link: http://www.responsibletourismawards.com/ December, 2009.

RIU Hotels \& Resorts

Link: http://www.riu.com/es/ December, 2009.

Sol Meliá

Link: http://www.solmelia.com/ December 2009.

The Code

Link: http://www.thecode.org/ December, 2009. 